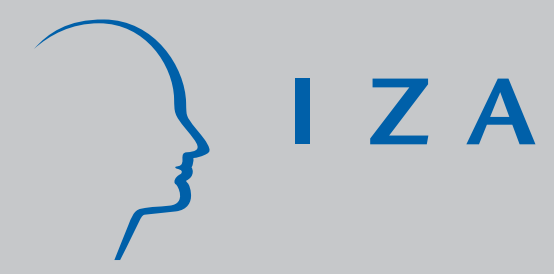

IZADP No. 1584

Differences in Desired and Actual Fertility: An Economic Analysis of the Spanish Case

AliciaAdsera

May 2005 


\title{
Differences in Desired and Actual Fertility: An Economic Analysis of the Spanish Case
}

\author{
Alicia Adsera \\ University of Illinois at Chicago, University of Chicago \\ and IZA Bonn
}

Discussion Paper No. 1584

May 2005

IZA
P.O. Box 7240
53072 Bonn
Germany

Phone: +49-228-3894-0

Fax: +49-228-3894-180

Email: iza@iza.org

\begin{abstract}
Any opinions expressed here are those of the author(s) and not those of the institute. Research disseminated by IZA may include views on policy, but the institute itself takes no institutional policy positions.

The Institute for the Study of Labor (IZA) in Bonn is a local and virtual international research center and a place of communication between science, politics and business. IZA is an independent nonprofit company supported by Deutsche Post World Net. The center is associated with the University of Bonn and offers a stimulating research environment through its research networks, research support, and visitors and doctoral programs. IZA engages in (i) original and internationally competitive research in all fields of labor economics, (ii) development of policy concepts, and (iii) dissemination of research results and concepts to the interested public.
\end{abstract}

IZA Discussion Papers often represent preliminary work and are circulated to encourage discussion. Citation of such a paper should account for its provisional character. A revised version may be available directly from the author. 


\section{ABSTRACT}

\section{Differences in Desired and Actual Fertility: An Economic Analysis of the Spanish Case*}

Family size is the outcome of sequential decisions influenced both by preferences and by ongoing changes in the environment where a family lives. During the last two decades the gap between the number of children women prefer and their actual fertility has widened in Spain. The paper uses the 1985 and 1999 Spanish Fertility Surveys to study whether the tightening of the labor market and worsening of economic conditions in Spain during the last twenty years are important determinants of this change. I find that women facing high unemployment rates in their mid-twenties tend to restrict their fertility below their ideal level. Among working-women, the stability of a public sector job lessens the difficulties of balancing work and family and of achieving preferred fertility. Temporary contracts work in the opposite direction. Findings are robust to the inclusion of controls for the use of family planning as well as within-couple discrepancies in either preferences or religious affiliation.

JEL Classification: $\quad \mathrm{J} 13, \mathrm{~J} 2, \mathrm{J6}, \mathrm{Z} 13$

Keywords: fertility, desired number of children, unemployment, family planning, religion

Corresponding author:

Alicia Adsera

Department of Economics

University of Illinois at Chicago

601 S. Morgan St.

Chicago, IL 60607

USA

Email: adsera@uic.edu

\footnotetext{
* This paper was made possible by Grant Numbers P30-HD18288 and T32-HD007302 from the NICHD. Its contents are solely the responsibility of the author and do not necessarily represent the official views of the $\mathrm{NIH}$.
} 


\section{INTRODUCTION}

Fertility behavior has undergone major changes in Europe in general and in Spain in particular during the last decades. Within a general trend of declining fertility rates in Europe, Spain has experienced the most dramatic fall in birth rates. The Spanish fertility rate dropped from 2.8 in 1975 to 1.15 in 1997 , only to recover very lightly to 1.2 in recent years. Although desired fertility also went down in Spain and across Europe generally, it fell at a slower pace than fertility rates (John Bongaarts 2001, Joshua R. Goldstein, Wolfgang Lutz and Maria Rita Testa 2003). As a result, the gap between ideal and achieved fertility increased in Spain in the last two decades. This paper employs the 1985 and 1999 Spanish Fertility Surveys to determine the nature and the determinants of this growing gap. Amending current research, which has emphasized the availability of contraceptives, heterogeneity of preferences within the couple and the religious make-up of the family, I show that economic conditions, and, more specifically, unemployment, are powerful determinants of the gap between preferred and actual fertility.

Although individual childbearing preferences are known to be reasonable predictors of future births (Ronald Freedman, Deborah Freedman and Arland Thornton 1980, Elizabeth Thomson, Elaine McDonald, and Larry L Bumpass 1990, Elizabeth Thomson 1997), they do not fully explain the observed level of fertility (Norman Ryder 1973, Charles Westoff and Norman Ryder 1977). To account for the gap between individual reproductive desires and fertility outcomes, scholars have traditionally resorted to the factors that characterize the individual and the union she forms such as religious practice, or certainty of initial preferences among other things (Evelyn Lehrer 1996, Robert Schoen et al. 1999). [footnote 1] 
However, the broad economic environment in which individuals make both work and fertility choices must also be a key factor in explaining any mismatch between women's (and men's) desires and their final realization.

During the last two decades, the high level of unemployment and its persistence have probably been the most important changes that have affected the lives of young Spaniards. The failure of young couples to obtain stable employment has notably restricted their ability to leave their parents home, obtain mortgages and, as I argue in this paper, make childbearing choices. The aim of the paper is to study whether the tightening of the labor market and worsening of economic conditions in Spain during the last two decades are important determinants of the widening of the mismatch between the number of children women consider ideal and their actual fertility. Further, the paper tests whether these findings are robust to the inclusion of additional relevant factors.

The paper is organized as follows. The first section explores the set of factors that may explain that mismatch between preferred and realized fertility. I first focus on how aggregate and individual economic and labor conditions affect individual fertility choices. I then discuss two alternative/complementary stories: use of family planning, and the effect on family-investments of within-couple differences in family-size preferences or in religious orientation. The second section describes the covariates as well as the methodology employed to test the different hypotheses. The third section presents the results both for the 1985 and 1999 Spanish Fertility Surveys (SFS). The fourth section concludes. 


\section{THE ANALYTICAL FRAMEWORK}

\section{Aggregate and Individual Economic Conditions}

Employment uncertainty since the mid 1980s has played a central role in the sharp fall of fertility rates and in the postponement of childbearing in all Western Europe (Alicia Adsera 2004 a, 2005). Unemployment rates for young women in Spain were close to $40 \%$ at several points during the last two decades. The long-term unemployment rate, the proportion of those who had been unemployed for more than a year among jobless, stayed over 50\% throughout the same period.

Both the 1985 and the 1999 SFS ask individuals about their reasons for either restricting their fertility or for the presence of a mismatch between their desired family size and their actual offspring. In the 1985 SFS women were asked whether they intended to have more children beyond their actual number and if not, why and under what conditions they would change their minds. Table 1.1 includes the responses among women in the sample of analysis. Less than half of those not intending to have more children had achieved their ideal number. Among those who had not attained the desired family size, the most cited reasons for restricting fertility were advanced age, concerns about the economy and health problems. Among those in the younger cohorts, economic constraints and economic pessimism about the future of their children were ranked at the top. An increase in the spouse's income and an improvement in economic conditions were the most cited basis that would encourage women to have more children.

Since unemployment rose sharply starting in the mid 1980s, economic conditions played an even more relevant role in the 1999 SFS. Table 1.2 tabulates the proportion of individuals that stated that there was a difference between their preferred fertility and their actual number of children and the reason for that mismatch. Over a third of women report the existence of a gap 
between their preferences and their actual fertility (36.6\%). Of those, around a third are still open to having more children as they consider their childbearing not finished. Among the rest, again, age and health problems are prominent on the list. But, most importantly, economic constraints are ranked at the top (26\% of all respondents). Necessity to work outside of the home and unemployment of either the woman or her spouse are also widely cited.

As unemployment became more persistent over recent decades, I expect to observe an increasing relevance of adverse economic conditions on childbearing choices from the 1985 SFS to the 1999 SFS. Cyclical and short-term unemployment may lead to a countercyclical fertility behavior. Women adjust their childbearing plans along the cycle to attain their preferred family size. However, in the presence of persistent une mployment, a withdrawal of the labor force to bear children likely carries long-term negative income effects. Women are likely to postpone childbearing until they achieve either a stable position or sufficient experience to easily land a job after childbearing. This results in a reduction of overall family size since women who become mothers late are expected to bear fewer children by the end of their fertile life (John Boongarts 2001). In addition to harsh aggregate economic conditions, unforeseen individual shocks such as the personal experience of a long-term unemployment spell may further discourage the already belated childbearing plans as families intensify their precautionary behavior.

Rampant unemployment in Spain was accompanied by a segmentation of the labor market by age. During the last two decades, mature workers in Spain held protected jobs while younger cohorts experienced high turnover rates across precarious jobs in the lower end of a dual market. Young women faced a choice of sticking to their unstable job trading off childbearing for the hope of employment security or struggling to re-enter the labor force after childbirth (Paula Adam 1996). Lack of employment stability among young men contributed further to depressing fertility 
(Namkee Ahn and Pedro Mira 2001, Maria Gutierrez-Domenech 2002). As a result, besides aggregate economic conditions, the particular type of employment that each woman (and her spouse) secures for herself is likely to have differential effects in her ability to fulfill her childbearing plans (Adsera 2004 a). Positions that shelter individuals from the uncertainty of job turnover, such as tenured jobs, should lessen the negative impact of aggregate conditions on achieved fertility and allow couples to move closer to the ir preferred family size. Among those, public sector jobs constitute the most stable type of labor contracts in European countries. I expect public employees to exhibit narrower mismatch in their fertility behavior than those working in more precarious positions in the private sector.

\section{Family Planning}

The health literature emphasizes the costs and the lack of access to contraceptives as key factors restricting the ability of a couple to control their family size. In our analysis, however, absence of family planning may operate in both directions. On the one hand, women with a stable partner who do not regularly use contraceptive methods are clearly more likely to exceed their preferred number of children. On the other hand, if the absence of family planning is due either to known infertility or to uncompleted fertility, women not using contraceptives should likely have smaller families than their preferred size.

The literature on interdenominational differences of fertility has noted the more pronatalist orientation of certain churches such as Conservative Protestants, Catholics, and especially Mormons (Evelyn Lehrer 1996). Among Catholics, a possible source of those differences may lie on Church teachings, which impose a restrictive use of contraception. Accordingly if Spain were considered mostly a Catholic country, the absence of family planning would lead to a high 
incidence of overshooting in the number of children. However, two observations conflict with this expectation. First, religious practice among Spanish Catholics has sharply decreased since the onset of democracy in 1975. Pablo Branas and Shoshana Neuman (2004) show how, even though the majority of Spaniards still define themselves as Catholics, only a minority attends Mass regularly and adheres to the main teachings of the Catholic Church. Further, it is widely acknowledged that adherence to Church recommendations among Catholics worldwide has weakened (Calvin Goldscheider and William D. Mosher 1991) and this seems to have happened at a relatively faster pace in Spain. The most recent data on the use of modern methods of contraception place Spain, where $67.5 \%$ of all married women of reproductive age use them (and $81 \%$ use some contraceptive method), at a level similar to that of Northern European countries or United States, and well above other traditionally Catholic countries such as Italy or Austria (with, respectively, a 39\% and 46.8\% prevalence of modern contraceptive use) (United Nations 2002). Further, among those who report a mismatch between actual and desired family size in the 1999 SFS, only less than $2 \%$ report to lack of familiarity with the use of contraceptives (see Table 1.2).

\section{Preference Differences within the Couple}

Researchers find that the predictive validity of reported preferences increases after an adjustment occurs early in the marriage and that within-couple discrepancy in desires also affects final parity (Robert Freedman, Deborah Freedman and Arland Thornton 1980, Arland Thornton, Robert Freedman and Deborah Freedman 1984). Within an economic framework, discrepancy among spouses on preferred family size should have a downward effect on fertility as children represent long-term financial commitments specific to the couple. Preference differences may indicate an increased frailty or lower quality of the union, and rational individuals may be less likely to incur 
in union-specific investments. Elizabeth Thomson's (1997) findings for the US confirm this hypothesis: couples disagreements about birth desires result in smaller families.

Still, given that some adjustment occurs along the marriage and that preferences reported later in a relationship may already embody the result of a bargaining process within the couple (Elizabeth Thomson, Elaine McDonald and Larry L. Bumpass 1990), an analysis of the discrepancy in desires at different points in time should bring important insights. Preference differences would likely be larger at time of marriage than when the couple has already lived together some time. [footnote 2] As a result, we may expect that a preference mismatch within a couple at the time of the marriage would explain better the gap between women's desires at the time of marriage and actual fertility than the gap with respect to preferences expressed later in the marriage.

\section{Religious Composition of the Couple}

Even if family size has been shown to vary across religious denominations and to be relatively larger among those with more frequent church attendance (William D. Mosher and Gerry E. Hendershot 1984, Linda B. Williams and Basil G. Zimmer 1990, William Sander 1992, Evelyn Lehrer 1996, Alicia Adsera 2004 b), its variation across religious groups should be explained by differences in preferences once other relevant factors are accounted for. Thus, we should not expect to observe any regularity across religious denominations and the gap between ideal and actual family size. As a matter of fact, researchers do not find any systematic discrepancy between the desired number of children and final parity across religions in the United States (Freedman et al. 1980). 
Nonetheless, religious differences within the couple may affect the gap between ideal and actual fertility as follows. Gary S. Becker, Elisabeth M. Landes and Robert T. Michael (1977) suggest that the religious composition of unions, whether inter-faith (heterogamous unions) or homogamous unions, should influence their fertility. Children represent "spouse-specific" human capital, capital that decreases in value following marriage dissolution. The lower stability of interfaith marriages should thus reduce the number of births within those marriages ("the marital stability effect"). Lehrer (1996 2004) notes a second pathway linking inter-faith marriage to low fertility. Spouses' religious denominations may have conflicting views with regard to family size. How spouses settle those differences ("the bargaining effect") depending on the particular religious composition of the couple may reinforce the first effect. Evelyn Lehrer and Carmel Chiswick (1993) find strong evidence of a larger fragility of intermarriages. Using U.S. data Lehrer (1996) finds support for the hypothesis that inter-faith couples restrict their fertility, even while the marriage is in place and that the extent of the effect depends on the particular composition of the marriage. Similarly, Adsera (2004 b) finds a slower transition to births among Spanish heterogamous couples, particularly among those with a non-Catholic spouse.

If, on average, interfaith couples invest less in spouse-specific capital, they are expected to restrict their fertility down from their preferred size. Thus this should result in a higher degree of mismatch between women's preferred and achieved fertility among inter-faith couples than among homogamous unions.

\section{DATA AND METHODOLOGY}

To explore the determinants of the gap between preferred and actual fertility I use the 1985 and 1999 Spanish Fertility Surveys (SFS), which were addressed to women aged 15 to 49 living in 
Spain. The surveys follow the guidelines of the Fertility Surveys from the United Nations. One woman was interviewed in each household. The total number of interviews available in the 1985 Survey was 8,782 and, for the purpose of this paper, we have complete information on 5,043 married women. In the 1999 Survey, a total of 7,749 respondents were interviewed and the sample used in the paper comprises 4,346 married women.

The analyses in this paper are restricted to marital fertility. Consensual unions were rare until recently. Though their prevalence is much higher among the youngest generation, first births within a consensual union only constitute $2.5 \%$ of total first births reported in the 1999 SFS.

Both the 1985 and 1999 SFS report the preferred family size of each woman at the time of the interview. The 1985 SFS also measured the preferred size at time of marriage for a small sample of women as well as that of their husbands as reported by the wives. [footnote 3]

The dependent variables of the paper are (1) the gap between currently desired and achieved fertility; and (2) the same gap with respect to the preferred number at the time of marriage. I construct two different dependent variables to see whether results are robust to the particular measure of desires employed or whether some type of adjustment in the preferences occurs over time, as that found by previous research (Akinrinola Bankole and Charles F. Westoff 1998, Freedman et al. 1980). Table 2.1 reports the means of the dependent variables across birth cohorts as well as the size of the sample, in brackets, when information about preference at time of marriage is used. I have divided the sample of each survey in two age groups: those who are closer to or at the end of their fertile life, women aged 38 to 49 and those who are under 38 years of age.

The mean of the dependent variable is negative for the 1985 SFS and positive for the 1999 SFS. A negative sign implies that the final family size has overshoot initial preferences whereas a positive number points to unattained ideal family size. 
In addition, Table 2.1 includes the actual number of children in the marriage. Family size went down from 3.84 children, among married women born before 1948, to 2.11 children among those aged over 38 in the 1999 SFS. The ideal number of children, however, only suffered a moderate decline from 2.86 to 2.44 for those same cohorts.

To examine what accounts for the mismatch, I consider the following variables (whose means are reported in Tables 2.2 and 2.3):

(1) Aggregate Labor Market Conditions. The provincial unemployment rate prevalent at the time the woman was 24 years old is used as a proxy of the early labor market opportunities for the wife (and, to some extent, her spouse). The mean unemployment rate sharply moves up from 6\% in the 1985 SFS to $15 \%$ in the 1999 SFS and reaches $20 \%$ for those born after 1961.

(2) Individual Employment. Neither survey includes a complete retrospective labor market history of the woman or her spouse but both provide general information on labor market activity. In the 1985 SFS I take into account whether the wife worked after getting married and for how many years as well as some characteristics of the last (or current) job held. The categories are white collar, blue collar, family help and businesswoman. [footnote 4]

The 1999 SFS contains information on the current work of both the wife and her husband. A set of dummies indicates, first, whether they work and, then, whether their contract is temporary and whether they work for the public sector. Around $43 \%$ of the women and $90 \%$ of the men in the sample currently work. Of those, around $28 \%$ of the women and $19 \%$ of the men work in the public sector and $21 \%$ of the women and $15 \%$ of the men have a temporary contract. Among those born after 1961, the proportion of women and men working under temporary contracts stands, respectively, at $29 \%$ and $23 \%$. As already noted, in the context of European markets a public sector job is in general a tenured position whereas temporary contracts are relatively fragile jobs. 
(3) Family Planning. Contraceptive use is available in both surveys. I code it as a dummy variable with a value of 1 if the respondent has never used family planning. The proportions are noticeable low, around $13 \%$ and $11 \%$ in each Survey respectively.

(4) Preference Differences. The 1985 survey provides information on the desired family size at the time of marriage for both the wife and her spouse for a small sub-sample of individuals (sample size in included in Table 2.2). I construct a dummy variable to record the presence of a difference in the desired number of children of both spouses as reported by the woman. Discrepancy in fertility desires among spouses occurs in $20 \%$ of those couples. Women desired either one or two more children than their spouses in $7 \%$ and $2.7 \%$ of all couples respectively. Conversely, men desired either one or two more children than their wife's in $5.4 \%$ and $1.56 \%$ of those couples. Since women tend to have a higher preferred fertility, the mean difference between women and men's desires is positive and equal to 0.057 .

(5) Religious Composition of the Couple. Only the 1999 SFS provides information on the religious affiliation of both spouses. The question is posed about current religious beliefs and no information is available on the religious family background. Since the majority of Spaniards have a Catholic upbringing, the main distinction between individuals is religious practice. Practicing and non-practicing Catholics are considered to belong to different groups. Adsera (2004 b) finds both groups to have distinctively different fertility patterns in Spain. The alternative categories include those with no affiliation, Muslims and Protestants. Inter-faith unions amount to $15 \%$ of the couples in the 1999 SFS.

(6) Control Variables. Duration of the marriage, age at marriage, children out-of-wedlock, religion, wife and husband's education at the time of the survey, region of residence as well as size of the city of residence are included in the analyses of both samples. City sizes for the 1985 SFS 
are rural, small (under 100,000 inhabitants) or large (over 100,000). Categories in the 1999 SFS are: rural (less 10,000), small (10,000-50,000), medium $(50,000-500,000)$ or large (over 500,000).

In the 1985 SFS four categories for religious affiliation of the woman are included: practicing Catholic, non-practicing Catholic, no religion and other religion (a small mixed group that contains mainly Muslims and Conservative Protestants). As shown in Appendix A, the majority of women $(61 \%)$ consider themselves practicing Catholics in the 1985 SFS but their share is only $51 \%$ among those born after 1947 . The 1999 Survey provides five distinct categories: practicing Catholic, non-practicing Catholic, no beliefs, other religion (mainly Muslims and Conservative Protestants) and own beliefs. In the 1999 SFS non-practicing Catholics (49\%) are already the major group.

Educational groups include those with primary or less, low secondary (the omitted category), completed high school, vocational school and two-year and four-year college degrees. [footnote 5] Additionally, in the 1985 estimates I control whether either the wife or the husband had more than 2 siblings and in the 1999 SFS whether the woman was a student and/or born abroad. Appendix A includes the means of the control variables in the estimates. Benchmark values are reported in brackets. Coefficients of the control variables are not reported in the Tables. However, at the end of next section I comment on the results for these controls and estimates can be obtained from the author.

\section{RESULTS}

Estimates are presented in Tables 3 and 4 for the 1985 SFS and in Table 5 for the 1999 SFS. The dependent variable in Tables 3 and 5 is the difference between a woman's ideal number of children at the time of the interview and her actual family size. In Table 4 the ideal family size is measured 
at the time of marriage. Results are presented for the complete sample in each survey and for two major age groups. Appendix B and $\mathrm{C}$ include the estimated number of children within a marriage as a function of the same covariates in Tables 3 to 5. They serve as useful reference to better interpret the results in the paper.

Aggregate and Individual Economic Conditions. The unemployment rate in the province of residence at the time the woman was 24 years of age enters positively and significantly in all estimates except for the oldest cohort in the 1985 SFS. It indicates that the higher the prevailing unemployment rate when the wife was in her mid-twenties, the wider the gap between desired and attained fertility. This confirms previous research that finds Spaniards to have postponed and restricted their fertility as a response to a negative income effect arising from the high and persistent unemployment rate in the country since the 1980s (Adsera 2004 a, 2005, Ahn and Mira 2001, Gutierrez-Domenech 2002). The coefficient for those born before 1948 is not significant. They faced an average unemployment rate around $2 \%$ during their early working years and did not still confront harsh economic constraints.

The coefficient for aggregate unemployment is somewhat smaller in Table 5. However, given that the unemployment rates these younger cohorts face are high and that their overall fertility is low, the implied effect of unemployment is large for individuals born after 1961. For workers that experience an unemployment rate of $20 \%$ in their mid-twenties (the average for the sample), the effect amounts to an increase of 0.154 in the gap between preferred and actual fertility. Table 6 includes simulations of the predicted gap in the 1999 SFS for different unemployment rates. 
With regard to individual labor market conditions I include a different set of variables for each survey based on the available questionnaire. For the 1985 SFS, having worked after marriage increases the gap for the older cohort in Tables 3 and 4. Still the coefficient is only half as large and marginally significant at $15 \%$ level in Table 3 when the current ideal number of children is used. Working women born before 1948 are further away from their preferred family size than those inactive. However, the difference in size between the coefficients in Tables 3 and 4 hints a lifetime adjustment of individual preferences to the work reality. The number of years worked after marriage also enters with a significant positive coefficient for the old cohort. Among those born after 1947, neither of the coefficients is significant in Tables 3 and 4 . These women may have probably learnt from the difficulties of balancing work and family from the previous generation, one of the first to enter the labor market more extensively, and adjusted their desires ex-ante. Still, when the type of job is excluded from the estimates, the coefficient for work after marriage for women born after 1947 is 0.143 and significant at $1 \%$.

The type of position a woman holds (or held as her last job) matters differently for each age cohort in the 1985 SFS. Again, these are not perfect measures of the job category since the omitted group includes those for which no type is specified. Still, it is interesting to see that family help enters significantly with a negative coefficient for those born before 1948. Women working as family help attain their preferred family size more often than those in other types of employment. This may also indicate a reverse causality problem of those women being selected into those types of jobs because of their conditions as mothers. This dataset does not provide complete labor histories that could help to disentangle this problem. In Appendix B, women who work in family help positions have significantly larger family sizes that other working-women. Similarly, whitecollar positions also enter negatively for the same cohort to imply fertility closer to (or beyond) 
desires than for either blue collar or businesswomen. All categories are significantly positive for the young group in Table 3 though with coefficients of different size and, when they are omitted, working after marriage becomes positive and significant. [footnote 6]

The 1999 SFS includes information on the current employment of both spouses but not on the overall labor market history. Still, since I control for age, education and place of residence of each individual, current employment is a good proxy of the labor activity over their fertile life. None of the coefficients for the characteristics of the husband's job is significant in Table 5 (and Appendix C). Workingwomen of both age groups are more likely to fail to achieve their desired family size than those who are inactive. The coefficient, though, is only marginally significant at $15 \%$ for those born before 1962 . The coefficient of working status is relatively smaller in column 1 of Table 5 when the fertility gap is estimated than in Appendix $\mathrm{C}$ when family size is analyzed. This indicates that, even if workingwomen have significantly lower family sizes than inactive women, their preferences conform, at least partially, to this reality. Table 6 simulates the gap between preferred and achieved fertility for different groups of women: inactive, working in the private sector with a permanent or a short-term contract as well as those employed by the public sector.

As noted, the number of fragile contractual relationships has increased during the last decades in Spain. Almost a third of working women born after 1961 are covered by short-term contracts that do not carry the same benefits and severance payments as the traditional permanent contracts (Juan J. Dolado, Carlos Garcia-Serrano and Juan F. Jimeno 2002). Furthermore the instability of those positions constitutes a barrier to long-term financial planning (mortgages, children). The positive and significant coefficient in column (1) indicates that the gap on fertility is 
wider for women with short-term contracts as opposed to those with tenured or permanent positions.

Finally, public sector employment constitutes a unique form of tenured job that protects the worker from the uncertainty of unemployment, is accompanied with generous leave programs and is the key to obtaining good financial treatment. The coefficient of women's public sector employment is negative, highly significant and about the same absolute size as the coefficient for working status in column (1) of Table 5. As a result, the gap between achieved and ideal fertility for non-working women or for those employed in the public sector is of similar size and smaller than that of women working in the private sector. Still, non-working women have the largest families and those employed in the private sector the smallest (Appendix C). The relative stability of a public sector position as compared to a private sector one allows women to more easily adjust her fertility plans to her preferences.

Family Planning. Lack of family planning enters significantly with a positive coefficient across all estimates in both surveys. On average those families that have never used any contraceptive method are still far from their desired family size. They are probably not using family planning either because they are certain of their infertility or because they are trying to conceive. [footnote 7] Remember that descriptive statistics indicate a widespread use of contraceptive methods among Spaniards. As a result, it is not surprising to find that lack of family planning does not lead to overshooting but, on the contrary, may be an indication of unfulfilled wants. The negative, highly significant and somewhat smaller coefficient of lack of family planning on the number of children within a marriage (Appendix B and C) supports this explanation. 
Preference Differences within the Couple. Column (4) in Tables 3 and 4 includes a dummy for inter-union differences in the desired number of children. This information is only available for a sub-sample of the 1985 SFS individuals. In Table 3, when the gap is measured in reference to the current ideal for the wife, the coefficient on within-couple preference mismatch is positive but only marginally significant at a 15\% level. However, in Table 4, when the ideal number of children at the time of marriage is used to construct the dependent variable, the coefficient is much larger and highly significant.

The positive coefficient in both tables indicates that, on average, when there is disagreement on preferred family size, a woman's offspring is smaller than her ideal. Further, the smaller coefficient in Table 3 indicates that initial discrepancy between spouses involves smaller gaps in fertility as reported later in the marriage. This finding is supported by results in the literature that indicate, first, that an adjustment of fertility preferences occurs early after marriage and, second, that preferences later in marriage may already embody inter-union disagreements (Freedman et al. 1980, Thomson et al. 1990). Unfortunately the survey does not provide information on current preferences for the men to pursue this line of inquiry any further.

As an additional exercise, I estimate the same model in column (4) of Table 4 by using the gap between the husband's ideal family size at the time of the marriage and the actual fertility of the couple as the dependent variable. The dummy for preference discrepancy among spouses is not significant. Thus, inter-union disagreement does not lead to any mismatch between the husband's desires and his ultimate family size as it happens for women's desires. [footnote 8] This could be the product of either a difference in the bargaining power within the couple in favor of the husband or a higher flexibility in the desires of women surveyed in 1985 as their marriage progresses. In any event, if within-couple conflict depresses couple-specific investments and brings down family 
size, the ultimate number of children is more likely to be closer to the husband's preferred size, which is, on average, lower. [footnote 9]

Religious composition of the couple. In Table 5 I use the information on the religious background of the spouse available in the 1999 SFS. As expected, differences in the religious composition of the couple affect the gap between desired and actual fertility. When the husband's religious denomination is different from the wife's, the actual number of children in the union is significantly lower than the one the women's prefers. Both a higher expected frailty of those unions and internal bargaining problems are likely pathways to a small family size. Results in Appendix $\mathrm{C}$ show that family size is indeed significantly smaller in inter-faith unions than in homogamous couples. Yet the coefficient in Table 5 is twice as large as that in Appendix C. Thus, the deviation from the ideal size is larger than the deviation from the average family size.

Control Variables. Finally I briefly comment on the main control variables. The latter the wife entered marriage, the most likely she will not achieve her desired family size. Delayed marriage and transitions to first birth have already been found to reduce fertility relative to desired family size. Older first-time mothers have lower complete fertility at the end of their fertile life (Bongaarts 2001). Similarly, the coefficient for student status is positive and significant. The number of children out-of-wedlock significantly increases the likelihood of overshooting preferred family size. Coefficients on years of marriage decrease in size as the number of years into marriage increases and the gap between desires and actual fertility closes. The number of siblings from either the wife or the husband enters negatively and with a significant coefficient in the 1985 SFS sample, particularly for those born before 1947. Spouses coming from larger families have a lesser 
tendency to fall short from their preferences. The size of the city of residence is not relevant for the 1985 SFS. However, in the 1999 SFS, the gap between desired and achieved fertility of individuals born before 1962 and living in large cities is higher than the rest. These families may be relatively more constrained in economic terms given the rapidly rising housing costs in main Spanish cities during the last fifteen years (Maria Consuelo Colom, Rosario Martinez and Maria Cruz Moles 2002).

As expected, the religious denomination of the wife does not have a major role in explaining disparity between preferred and actual number of children in either survey. Only Catholic practicing women born before 1948 are short of attaining their preferred family size even if they do not show any significant difference in family size with respect to non-practicingand those without religion born after 1961 exceed their preferences.

Finally, there are not important differences in the gap between ideal and actual fertility among educational groups, even if their fertility behavior is different. In the 1999 SFS, women married to men with intermediate levels of education, either high-school or vocational school, tend to display lower fertility than preferred.

\section{CONCLUSIONS}

Family size is the outcome of sequential decisions influenced both by preferences and by ongoing changes in the environment where a family lives. In this paper I use the 1985 and 1999 Spanish Fertility Surveys to study what are the determinants of the mismatch between desired and actual fertility and whether some of these factors have become more or less relevant in between surveys. While the mean of the gap between preferred and achieved fertility was negative in the 
1985 Survey, it is positive in the 1999 Survey. More women fell short of their initial preferred size in the last survey.

The economic conditions under which childbearing decisions are made affect the ultimate parity of a couple. High and stubborn unemployment in Spain during the last two decades has greatly increased economic uncertainty of young cohorts and resulted in extensive childbearing postponement. Late mothers are less likely to attain their intended family size, even if it is already lower than their desired. As a proxy for labor market conditions at the onset of a career, I have shown that fertility of women facing high unemployment rates in their mid-twenties is below their preferred level.

Further, I explore what job characteristics may shelter individuals from labor market uncertainty and facilitate the dual role of mother-worker. I find that the stability of public sector jobs lessens the difficulties women face of balancing work and family and of achieving preferred fertility. The gap between desired and actual fertility for those employed in the public sector is of similar size as for those inactive and smaller than for women in the private sector. Further results indicate that temporary contracts intensify women's uncertainty and add up to the obstacles of work to widen the fertility mismatch.

In addition, results confirm that widespread availability and use of family planning has contributed to the widening of the gap between desires and achieved fertility in the European Union where fewer women are overshooting their preferred size (Fahey and Speder 2004). Finally, within couple discrepancy in either preferences or religious affiliation is shown to depress familyspecific investments such as children. 
Appendix A. Means of Control Variables 1985 and 1999

\begin{tabular}{|c|c|c|}
\hline & 1985 SFS & $1999 \mathrm{SFS}$ \\
\hline Age at marriage & 23.27 & 23.64 \\
\hline Children out-of-wedlock & 0.04 & 0.04 \\
\hline Student & n.a. & 0.08 \\
\hline \multicolumn{3}{|l|}{ Years of Marriage } \\
\hline $0-2$ & 0.06 & 0.06 \\
\hline $3-4$ & 0.06 & 0.07 \\
\hline $5-6$ & 0.07 & 0.07 \\
\hline $7-8$ & 0.09 & 0.08 \\
\hline $9-10$ & 0.09 & 0.08 \\
\hline $11-12$ & 0.10 & 0.08 \\
\hline $13-14$ & 0.10 & 0.08 \\
\hline (15 or more) & 0.44 & 0.48 \\
\hline \multicolumn{3}{|l|}{ Siblings $3+$} \\
\hline Wife & 0.42 & n.a. \\
\hline Husband & 0.45 & n.a. \\
\hline Foreign Born & n.a. & 0.03 \\
\hline \multicolumn{3}{|l|}{ Size of City } \\
\hline Rural & $(0.56)$ & 0.17 \\
\hline Small & 0.22 & 0.25 \\
\hline Medium & n.a. & $(0.46)$ \\
\hline Large & 0.22 & 0.12 \\
\hline \multicolumn{3}{|l|}{ Wife's Religion } \\
\hline (Non-Practicing Catholic) & 0.36 & 0.49 \\
\hline Practicing Catholic & 0.61 & 0.43 \\
\hline Own Beliefs & n.a. & 0.03 \\
\hline No Religion & 0.02 & 0.03 \\
\hline Other Religion & 0.01 & 0.02 \\
\hline \multicolumn{3}{|l|}{ Wife's Education } \\
\hline Primary or less & 0.65 & 0.27 \\
\hline (Low Secondary) & 0.19 & 0.31 \\
\hline High School & 0.09 & 0.12 \\
\hline Vocational & n.a. & 0.15 \\
\hline College (2 y.) & 0.05 & 0.07 \\
\hline College (4 y.) & 0.02 & 0.08 \\
\hline \multicolumn{3}{|l|}{ Husband's Education } \\
\hline Primary or Less & 0.57 & 0.25 \\
\hline (Low Secondary) & 0.17 & 0.30 \\
\hline
\end{tabular}




\begin{tabular}{lll}
\hline High School & 0.15 & 0.15 \\
Vocational & & 0.13 \\
College (2 y.) & 0.05 & 0.06 \\
College (4 y.) & 0.05 & 0.10 \\
& & \\
Region of Residence & & \\
Andalucia & 0.11 & 0.15 \\
Aragon & 0.04 & 0.05 \\
Asturias & 0.04 & 0.04 \\
Cantabria & 0.03 & 0.02 \\
Castilla La Mancha & 0.05 & 0.05 \\
Castilla Leon & 0.06 & 0.07 \\
Catalunya & 0.11 & 0.09 \\
Extremadura & 0.04 & 0.04 \\
Galicia & 0.07 & 0.07 \\
Baleares & 0.04 & 0.03 \\
Canarias & 0.04 & 0.06 \\
La Rioja & 0.03 & 0.03 \\
Madrid & 0.08 & 0.08 \\
Murcia & 0.04 & 0.05 \\
Navarra & 0.03 & 0.03 \\
Pais Vasco & 0.06 & 0.04 \\
Valencia & 0.08 & 0.07 \\
(Ceuta Melilla) & 0.03 & 0.03 \\
& & \\
N. Observations & 5043 & 4346
\end{tabular}

Note: Benchmark values in parentheses. n.a. the category was not available in the survey. 
Appendix B. Number of children within marriage in 1985 SFS.

\begin{tabular}{lcc}
\hline & All & All \\
\hline Aggregate conditions province & & \\
Unemploy. Rate Province when & -3.210 & -2.694 \\
wife 24 yrs. & $(-7.53)^{* *}$ & $(-3.75)^{* *}$ \\
& & \\
Wife's work & -0.054 & -0.056 \\
Worked after marriage & $(-1.03)$ & $(-0.77)$ \\
Years worked & -0.016 & -0.030 \\
& $(-3.29)^{* *}$ & $(-3.60)^{* *}$ \\
Last job & 0.047 & \\
White Collar & $(0.71)$ & 0.054 \\
& -0.138 & $(0.54)$ \\
Blue Collar & $(-2.20)^{* *}$ & -0.001 \\
& 0.139 & $(-0.01)$ \\
Family Help & $(1.63)^{*}$ & 0.259 \\
& -0.147 & $(1.93)^{*}$ \\
Business-woman & $(-1.48)$ & 0.017 \\
Contraception & & $(0.13)$ \\
No Family Planning & -0.187 & -0.399 \\
Difference in desired number & $(-3.08)^{* *}$ & $(-3.61)^{* *}$ \\
within the couple & & 0.099 \\
Constant & & $(1.51)^{\#}$ \\
& 5.81 & 5.571 \\
N. Obs & $(30)^{* *}$ & $(16.1)^{* *}$ \\
Adj-R Squared & 5043 & 1591 \\
\hline Note: OLS estinas & 0.428 \\
\hline
\end{tabular}

Note: OLS estimates include controls for wife's foreign birth, wife's religious affiliation, out of wedlock, age at marriage, years of marriage, size of city and region of residence as well as the couple's education. Significance levels: ** less than $5 \%$, * less than $10 \%$, \# less than $15 \%$. 
Appendix C. Number of children within marriage in 1999 SFS.

\begin{tabular}{lc}
\hline & All \\
\hline Aggregate conditions & -1.495 \\
Unemploy. Rate Province when wife 24 yrs. & $(-6.70)^{* *}$ \\
Wife's current work & -0.165 \\
Works=1 & $(-5.27)^{* *}$ \\
Temporary Contract & -0.041 \\
Public Sector Job & $(-0.85)$ \\
& 0.116 \\
Husband's current work & $(2.44)^{* *}$ \\
Works=1 & -0.043 \\
Temporary Contract & $(-0.98)$ \\
Public Sector Job & -0.011 \\
& $(-0.29)$ \\
Contraception & -0.036 \\
No Family Planning & $(-0.98)$ \\
Husband's Religion & \\
Different than wife's & -0.349 \\
& $(-8.43)^{* *}$ \\
N. Obs & \\
Adj-R Squared & -0.078 \\
Note: OLS entant & $(-2.18)^{* *}$ \\
& 3.676 \\
& $(26.15)^{* *}$ \\
& 4346 \\
& 0.35 \\
\hline
\end{tabular}

Note: OLS estimates include controls for wife's foreign birth, age at marriage, wife's religious affiliation, out of wedlock children, years of marriage, size of city and region of residence as well as the couple's education. Significance levels: ** less than $5 \%$, * less than $10 \%$, \# less than $15 \%$. 


\section{NOTES:}

(1) Bongaarts (1990) offers a review of some of the potential biases in measures of desired fertility.

(2) Adjustment of intentions about a child increases with time since childbirth occurs (Akinrinola Bankole and Charles F. Westoff. 1998).

(3) Previous research supports the accuracy of wife's reports of husband's fertility preferences (S. Phillip Morgan 1985, Williams and Thomson 1985, Frances K. Goldscheider and Gayle Kaufman 1996).

(4) Unfortunately, the omitted category refers to those without information about the job (around $13 \%$ of all individuals). Estimates are robust to the exclusion of variables that describe the type of job and results can be obtained from the author. Still I choose to include them because some coefficients provide interesting variations across job categories.

(5) In Spain vocational schools are offered as a parallel track to high school and community colleges.

(6) In separate estimates, available from the author, current unemployment status of the husband enters negatively and significantly in some of the specifications. Families burdened by difficult economic conditions may revise their preferred number of children downward.

(7) In separate estimates that exclude women who are known to be infertile, coefficients on lack of family planning are still positive and significant.

(8) Results are available from the author.

(9) Freedman et al. (1980) find that women's preferences tend to adjust to reduce inter-couple difference but that final parity is more likely to adjust downward than upward to meet spouse's ideal. Interestingly, Elizabeth Thomson and Jan M. Hoem (1998) found that Swedish couples with 
preference differences had lower childbearing, but both the woman and her spouse were equally likely to prevail in the face of a disagreement. 


\section{REFERENCES}

Adsera, Alicia 2004 a. "Changing Fertility Rates in Developed Markets. The Impact of Labor Market Institutions.” Journal of Population Economics 17: 17-43. . 2004 b. "Marital Fertility and Religion: Recent Changes in Spain." Discussion Paper,

Population Research Center 2004-02, University of Chicago. . 2005. "Vanishing Children: From High Unemployment to Low Fertility in Developed

Countries." American Economic Review Papers and Proceedings, forthcoming.

Adam, Paula 1996. "Mothers in an insider-outsider economy: The puzzle of Spain.” Journal of Population Economics 9:301-323.

Ahn, Namkee and Pedro Mira. 2001. "Job bust, baby bust? Evidence from Spain." Journal of Population Economics 14:505-521.

Becker, Gary S., Elisabeth M. Landes and Robert T. Michael. 1977. “An Economic Analysis of Marital Instability." Journal of Political Economy 85 (6): 1141-1187.

Bankole, Akinrinola and Charles F. Westoff. 1998. "The consistency and Validity of Reproductive Attitudes: Evidence from Morocco.” Journal of Biosocial Science 30 (4): 438-455.

Bongaarts, John 1990. "The Measurement of Wanted Fertility." Population and Development Review 16: 487-506. . 2001. "Fertility and Reproductive Preferences in Post-Transitional Societies."

Population and Development Review 27: 260-281.

Branas, Pablo and Shoshana Neuman. 2004. "Analyzing Religiosity Within an economic

Framework: The Case of Spanish Catholics." Review of Economics of the Household 2 (1): 5-22. 
Colom, Maria Consuelo, Rosario Martinez and Maria Cruz Moles. 2002 "Un analisis de las decisions de formacion de hogar, tenencia y demanda de servicios de viviendas de los jovenes espanoles.” Moneda y Credito 215: 199-223.

Dolado, Juan J., Carlo s García-Serrano and Juan F. Jimeno, 2002. "Drawing Lessons from the Boom of Temporary Jobs in Spain.” The Economic Journal, 112: 270-295.

Fahey, Tony and Zsolt Speder. 2004. Fertility and family issues in an enlarged Europe. European Foundation for the Improvement of Living and Working Conditions, Dublin.

Freedman, Ronald, Deborah Freedman and Arland Thornton. 1980. "Changes in Fertility Expectations and Preferences between 1962 and 1977: Their Relation to Final Parity.” Demography 17 (4): 365-378.

Goldscheider, Frances K. and Gayle Kaufman. 1996. "Fertility and Commitment: Bringing Men Back in.” Population and Development Review 22 (Suppl.): 87-99.

Goldscheider, Calvin and William D. Mosher. 1991. "Patterns of contraceptive use in the United States: The importance of religious factors." Studies in Family Planning 22 (2): $102-115$.

Goldstein, Joshua R., Wolfgang Lutz and Maria Rita Testa. 2003. "The emergence of Subreplacement Family Size Ideals in Europe." Population Research and Policy Review 22: 479-496.

Gutierrez-Domenech, Maria. 2002. "The Impact of the Labor Market on the Timing of Marriage and Births in Spain." CEP working paper.

Instituto Nacional de Estadistica (INE) 1985. Encuesta de Fecundidad 1985, Madrid. 1999. Encuesta de Fecundidad 1999, Madrid. 
Lehrer, Evelyn L. 1996. "Religion as a determinant of marital fertility." Journal of Population Economics 9: 173-196. . 2004. "Religion as a Determinant of Economic and Demographic Behavior in the United States.” Population and Development Review 30 (4): 707-726.

Lehrer, Evelyn L. and Carmel U. Chiswick. 1993. "Religion as a Determinant of Marital Stability." Demography 30 (3): 385-404.

Morgan, S. Philip 1985. "Individual and Couple Intentions for More Children: A Research Note." Demography 22 (1): 125-132.

Mosher, William D. and Gerry E. Hendershot. 1984. "Religion and Fertility: A Replication." Demography 21 (2): 185-191.

Ryder, Norman B. 1973. A Critique of the National Fertility Study, Demography 10 (4): 495-506. Sacerdote, Bruce and Edward Glaeser. 2001. "Education and Religion.” NBER working paper $\mathrm{N}$. 8080.

Sander, William. 1992. "Catholicism and the Economics of Fertility." Population Studies 46: 477489.

Schoen, Robert, Nan Marie Astone, Young J. Kim, Constance Nathanson and Jason M. Fields. 1999 “Do Fertility Intentions affect Fertility Behavior?” Journal of Marriage and the Family 1999 (3): 790-799.

Thomson, Elizabeth 1997. "Couple Childbearing Desires, Intentions and Births." Demography 34 (3): 343-354.

Thomson, Elizabeth and Jan M. Hoem. 1998. "Couple Childbearing Plans and Births in Sweden." Demography 35(3): 315-322. 
Thomson, Elizabeth, Elaine McDonald, and Larry L Bumpass. 1990. "Fertility Desires and Fertility: Hers, His and Theirs.” Demography 27: 579-588.

Thornton, Arland Ronald Freedman and Deborah Freedman. 1984. "Further Reflections on Changes in Fertility Expectations and Preferences.” Demography 21 (3): 423-429.

United Nations. 2002. World Contraceptive Use 2001. Population Division of the Department of Economic and Social Affairs of the United Nations Secretariat, New York.

Westoff, Charles and Norman B. Ryder. 1977. "The Predictive Validity of Reproductive Intentions." Demography 14 (4): 431-453.

Williams, Linda B. and Basil G. Zimmer. 1990. "The Changing Influence of Religion on US Fertility: Evidence from Rhode Island.” Demography 27 (3): 475-481.

Williams, Richard and Elizabeth Thomson. 1985. "Can Spouses be Trusted? A Look at Husband/wife Proxy Reports.” Demography 22 (1): 115- 123. 
Table 1.1 Main reason for restricting fertility and main reason that would revert this decision among women who do not plan to have more children in 1985 SFS

\section{All}

Born 1948+

\section{Reasons for restricting fertility}

Achieved desired family size

38.05

16.92

43.83

Too old for childbearing

13.29

Lack of Economic Resources

11.28

16.62

Pessimism about future economic conditions

7.38

15.26

Health problems

5.39

5.83

Afraid child will have health problems

2.29

4.34

Want/need to work outside home

2.08

4.21

Hardships of raising children

1.61

3.12

Spouse unemployed

0.87

2.31

Excessive housework

0.43

1.42

Small house

0.12

0.54

Ongoing studies

0.06

0.27

Lack of child-care centers

0.14

\section{Reasons that would change your mind}

None

80.6

Other reasons

6.38

71.23

Improvement in economic conditions

5.73

Increase in spouse's earnings

4.46

9.43

No need to work outside home

1.18

6.78

Better housing availability

0.65

2.04

Increase in own earnings

0.5

1.22

Part-time

0.28

0.68

More child-care centers

0.12

0.47

0.27

Note: Percentage citing each reason only among women in the sample used for the estimates. 
Table 1.2 Proportion with Preferred and Actual Fertility Mismatch and Reasons Cited for Mismatch in 1999 SFS

\section{Do Actual and Preferred Fertility Coincide?}

$\%$

Yes

63.42

No

36.58

If not, Why? (*)

Have not completed family

$\%$ citing

Lack of Economic Resources

31.4

Health problems

26.1

16.6

Want/Need work outside Home

13.2

Hardships of raising children

9.1

Failure of contraceptive method

8.5

Too old for childbearing

7.7

Unemployment (self/spouse)

5.4

Pregnancy/ Labor hard work

4.9

Small house

4.9

Afraid child will have health problems

4.9

Other

3.2

Too much housework

2.4

Lack of child care centers

2.1

Lack familiarity with contraceptives

1.9

Child limits freedom for leisure

1.5

Study

0.9

Note: It only includes women in the sample used for the estimates. (*) Respondents were allowed to give more than one reason for the mismatch. 
Table 2.1 Dependent Variables

\begin{tabular}{lccc}
\hline \multicolumn{1}{c}{1985} & All & Born 1947- & Born 1948+ \\
Diff. Ideal at marriage-Achieved & $-0.53(2045)$ & $-0.87(741)$ & $-0.33(1304)$ \\
Diff. Ideal now-Achieved & -0.65 & -0.98 & -0.34 \\
Children in marriage & 3.32 & 3.84 & 2.85 \\
& & & \\
1999 & All & Born 1961- & Born 1962+ \\
Diff. Ideal Achieved & 0.47 & 0.33 & 0.65 \\
Children in marriage & 1.81 & 2.11 & 1.44
\end{tabular}

Note: Number of observations for the sample including information on spouse's preferences in parentheses.

Table 2.2 Means of Variables 1985 SFS

\begin{tabular}{|c|c|c|c|}
\hline & All & Born 1947- & Born 1948+ \\
\hline $\begin{array}{l}\text { Aggregate conditions province } \\
\text { Unemployme nt Rate Province } \\
\text { when wife } 24 \text { yrs. }\end{array}$ & 0.06 & 0.02 & 0.09 \\
\hline $\begin{array}{l}\text { Wife's work } \\
\text { Worked after marriage } \\
\text { Years worked }\end{array}$ & $\begin{array}{l}0.46 \\
3.54\end{array}$ & $\begin{array}{l}0.42 \\
4.47\end{array}$ & $\begin{array}{l}0.50 \\
2.68\end{array}$ \\
\hline $\begin{array}{l}\text { Last job } \\
\text { White Collar } \\
\text { Blue Collar } \\
\text { Family Help } \\
\text { Business-woman }\end{array}$ & $\begin{array}{l}0.11 \\
0.11 \\
0.07 \\
0.04\end{array}$ & $\begin{array}{l}0.10 \\
0.08 \\
0.08 \\
0.03\end{array}$ & $\begin{array}{l}0.13 \\
0.14 \\
0.06 \\
0.05\end{array}$ \\
\hline $\begin{array}{l}\text { Contraception } \\
\text { No Family Planning }\end{array}$ & 0.13 & 0.16 & 0.10 \\
\hline $\begin{array}{l}\text { Difference in preferences within } \\
\text { couple }\end{array}$ & $0.20(1591)$ & $0.24(541)$ & $0.18(1050)$ \\
\hline N. Observations & 5043 & 2411 & 2632 \\
\hline
\end{tabular}


Table 2.3 Means of Variables 1999 SFS

\begin{tabular}{llcc}
\hline & All & Born 1961- & Born 1962+ \\
\hline $\begin{array}{l}\text { Aggregate conditions } \\
\text { Unemployment Rate Province } \\
\text { when wife 24 yrs. }\end{array}$ & 0.15 & 0.11 & \\
& & & 0.20 \\
Wife's current work & 0.43 & 0.41 & 0.45 \\
$\begin{array}{l}\text { Works=1 } \\
\text { Temporary Contract }\end{array}$ & 0.09 & 0.07 & 0.13 \\
Public Sector Job & 0.12 & 0.13 & 0.11 \\
$\begin{array}{l}\text { Husband's current work } \\
\text { Works=1 }\end{array}$ & 0.90 & & \\
Temporary Contract & 0.14 & 0.89 & 0.92 \\
Public Sector Job & 0.17 & 0.10 & 0.21 \\
& & & 0.15 \\
Contraception & 0.11 & 0.15 & 0.06 \\
No Family Planning & & & \\
Husband's Religion & 0.15 & 0.16 & 0.14 \\
Different than wife's & 4346 & 2431 & 1915 \\
\hline N. Observations & & & \\
\hline
\end{tabular}


Table 3. Difference between current ideal and actual number of children in 1985 SFS.

\begin{tabular}{|c|c|c|c|c|}
\hline & All & Born 1947- & Born 1948+ & All \\
\hline \multicolumn{5}{|l|}{ Aggregate conditions } \\
\hline $\begin{array}{l}\text { Unemployment Rate Province } \\
\text { when wife } 24 \text { yrs. }\end{array}$ & $\begin{array}{c}2.336 \\
(4.50)^{* *}\end{array}$ & $\begin{array}{l}4.647 \\
(1.38)\end{array}$ & $\begin{array}{c}1.156 \\
(1.98)^{* *}\end{array}$ & $\begin{array}{c}1.668 \\
(1.89)^{*}\end{array}$ \\
\hline \multicolumn{5}{|l|}{ Wife's work } \\
\hline Worked after marriage & $\begin{array}{c}0.098 \\
(1.67)^{*}\end{array}$ & $\begin{array}{l}0.159 \\
(1.53) \#\end{array}$ & $\begin{array}{l}0.017 \\
(0.27)\end{array}$ & $\begin{array}{c}0.149 \\
(1.62)^{*}\end{array}$ \\
\hline Years worked & $\begin{array}{l}0.005 \\
(0.87)\end{array}$ & $\begin{array}{c}0.014 \\
(1.94)^{*}\end{array}$ & $\begin{array}{l}-0.006 \\
(-0.70)\end{array}$ & $\begin{array}{c}0.014 \\
(1.44) \#\end{array}$ \\
\hline \multicolumn{5}{|l|}{ Last job } \\
\hline White Collar & $\begin{array}{l}0.066 \\
(0.85)\end{array}$ & $\begin{array}{c}-0.289 \\
(-2.19)^{* *}\end{array}$ & $\begin{array}{c}0.331 \\
(3.73)^{* *}\end{array}$ & $\begin{array}{l}0.157 \\
(1.18)\end{array}$ \\
\hline Blue Collar & $\begin{array}{l}0.095 \\
(1.32)\end{array}$ & $\begin{array}{l}0.001 \\
(0.01)\end{array}$ & $\begin{array}{c}0.238 \\
(2.97)^{* *}\end{array}$ & $\begin{array}{l}0.017 \\
(0.16)\end{array}$ \\
\hline Family Help & $\begin{array}{l}0.002 \\
(0.02)\end{array}$ & $\begin{array}{c}-0.270 \\
(-1.98)^{* *}\end{array}$ & $\begin{array}{c}0.242 \\
(2.20)^{* *}\end{array}$ & $\begin{array}{l}-0.150 \\
(-0.91)\end{array}$ \\
\hline Busine ss-woman & $\begin{array}{c}0.199 \\
(1.65)^{*}\end{array}$ & $\begin{array}{l}0.113 \\
(0.52)\end{array}$ & $\begin{array}{c}0.281 \\
(2.10)^{* *}\end{array}$ & $\begin{array}{l}0.063 \\
(0.37)\end{array}$ \\
\hline \multicolumn{5}{|l|}{ Contraception } \\
\hline No Family Planning & $\begin{array}{c}0.232 \\
(3.65)^{* *}\end{array}$ & $\begin{array}{l}0.081 \\
(0.93)\end{array}$ & $\begin{array}{c}0.487 \\
(5.40)^{* *}\end{array}$ & $\begin{array}{c}0.479 \\
(3.39)^{* *}\end{array}$ \\
\hline $\begin{array}{l}\text { Difference in preferences } \\
\text { within couple }\end{array}$ & & & & $\begin{array}{c}0.126 \\
(1.52) \#\end{array}$ \\
\hline Constant & $\begin{array}{c}-2.692 \\
(-12.85) * *\end{array}$ & $\begin{array}{c}-3.302 \\
(-8.39)^{* *}\end{array}$ & $\begin{array}{l}-2.188 \\
(-7.36) * *\end{array}$ & $\begin{array}{c}-2.351 \\
(-6.75)^{* *}\end{array}$ \\
\hline N. Obs & 5043 & 2411 & 2632 & 1591 \\
\hline Adj-R Squared & 0.220 & 0.136 & 0.276 & 0.240 \\
\hline
\end{tabular}

Note: OLS estimates include controls for wife's foreign birth, age at marriage, years of marriage, wife's religious affiliation, children out-of-wedlock, size of city and region of residence as well as the couple's education. Significance levels: ** less than 5\%, * less than $10 \%$, \# less than $15 \%$. 
Table 4. Difference between ideal at time of marriage and actual number of children in 1985 SFS.

\begin{tabular}{|c|c|c|c|c|}
\hline & All & Born 1947- & $\begin{array}{c}\text { Born } \\
1948+\end{array}$ & All \\
\hline \multicolumn{5}{|l|}{ Aggregate conditions } \\
\hline $\begin{array}{l}\text { Unemployment Rate Province } \\
\text { when wife } 24 \text { yrs. }\end{array}$ & $\begin{array}{c}3.066 \\
(3.75)^{* *}\end{array}$ & $\begin{array}{l}-1.030 \\
(-0.17)\end{array}$ & $\begin{array}{l}1.371 \\
(1.38)\end{array}$ & $\begin{array}{c}2.802 \\
(3.22) * *\end{array}$ \\
\hline \multicolumn{5}{|l|}{ Wife's work } \\
\hline Worked after marriage & $\begin{array}{l}0.085 \\
(0.89)\end{array}$ & $\begin{array}{c}0.326 \\
(1.72)^{*}\end{array}$ & $\begin{array}{l}-0.116 \\
(-1.10)\end{array}$ & $\begin{array}{l}0.044 \\
(0.46)\end{array}$ \\
\hline Years worked & $\begin{array}{c}0.022 \\
(2.00)^{* *}\end{array}$ & $\begin{array}{c}0.030 \\
(1.81)^{*}\end{array}$ & $\begin{array}{l}0.003 \\
(0.24)\end{array}$ & $\begin{array}{c}0.028 \\
(2.24) * *\end{array}$ \\
\hline \multicolumn{5}{|l|}{ Last job } \\
\hline White Collar & $\begin{array}{c}-0.194 \\
(-1.77)^{*}\end{array}$ & $\begin{array}{c}-0.638 \\
(-2.50)^{* *}\end{array}$ & $\begin{array}{l}0.107 \\
(0.94)\end{array}$ & $\begin{array}{l}-0.088 \\
(-0.76)\end{array}$ \\
\hline Blue Collar & $\begin{array}{l}0.039 \\
(0.34)\end{array}$ & $\begin{array}{l}-0.268 \\
(-1.15)\end{array}$ & $\begin{array}{c}0.329 \\
(2.66) * *\end{array}$ & $\begin{array}{l}-0.005 \\
(-0.04)\end{array}$ \\
\hline Family Help & $\begin{array}{l}-0.183 \\
(-1.20)\end{array}$ & $\begin{array}{l}-0.580 \\
(-1.75)^{*}\end{array}$ & $\begin{array}{l}0.123 \\
(0.73)\end{array}$ & $\begin{array}{l}-0.291 \\
(-1.83)^{*}\end{array}$ \\
\hline Business-woman & $\begin{array}{l}0.051 \\
(0.29)\end{array}$ & $\begin{array}{l}0.017 \\
(0.04)\end{array}$ & $\begin{array}{l}0.276 \\
(1.47) \#\end{array}$ & $\begin{array}{l}0.107 \\
(0.58)\end{array}$ \\
\hline Contraception & & & & \\
\hline No Family Planning & $\begin{array}{c}0.232 \\
(3.65)^{* *}\end{array}$ & $\begin{array}{l}0.081 \\
(0.93)\end{array}$ & $\begin{array}{c}0.487 \\
(5.40)^{* *}\end{array}$ & $\begin{array}{c}0.479 \\
(3.39)^{* *}\end{array}$ \\
\hline $\begin{array}{l}\text { Difference in preferences } \\
\text { within couple }\end{array}$ & & & & $\begin{array}{c}0.209 \\
(2.15)^{* *}\end{array}$ \\
\hline Constant & $\begin{array}{l}-2.730 \\
(-7.84) * *\end{array}$ & $\begin{array}{l}-4.204 \\
(-5.83)^{* *}\end{array}$ & $\begin{array}{c}-1.280 \\
(-2.63)^{* *}\end{array}$ & $\begin{array}{c}-2.492 \\
(-6.49) * *\end{array}$ \\
\hline N. Obs & 2045 & 741 & 1304 & 1591 \\
\hline Adj-R Squared & 0.187 & 0.148 & 0.234 & 0.190 \\
\hline
\end{tabular}

Note: OLS estimates include controls for wife's foreign birth, age at marriage, years of marriage, wife's religious affiliation, children out-of-wedlock, size of city and region of residence as well as the couple's education. Significance levels: ** less than 5\%, * less than $10 \%$, \# less than $15 \%$. 
Table 5. Difference between current ideal and actual number of children in 1999 SFS.

\begin{tabular}{|c|c|c|c|}
\hline & All & Born 1961- & Born 1962+ \\
\hline \multicolumn{4}{|l|}{ Aggregate conditions } \\
\hline $\begin{array}{l}\text { Unemployment Rate Province } \\
\text { when wife } 24 \text { yrs. }\end{array}$ & $\begin{array}{c}0.465 \\
(1.84)^{*}\end{array}$ & $\begin{array}{l}0.565 \\
(1.55) \#\end{array}$ & $\begin{array}{c}0.770 \\
(1.66)^{*}\end{array}$ \\
\hline \multicolumn{4}{|l|}{ Wife's current work } \\
\hline Works $=1$ & $\begin{array}{c}0.137 \\
(3.84)^{* *}\end{array}$ & $\begin{array}{c}0.077 \\
(1.49) \#\end{array}$ & $\begin{array}{c}0.201 \\
(4.16)^{* *}\end{array}$ \\
\hline Temporary Contract & $\begin{array}{c}0.095 \\
(1.75)^{*}\end{array}$ & $\begin{array}{c}0.128 \\
(1.46) \#\end{array}$ & $\begin{array}{l}0.060 \\
(0.90)\end{array}$ \\
\hline Public Sector Job & $\begin{array}{c}-0.139 \\
(-2.58)^{* *}\end{array}$ & $\begin{array}{c}-0.141 \\
(-1.83)^{*}\end{array}$ & $\begin{array}{c}-0.126 \\
(-1.67)^{*}\end{array}$ \\
\hline \multicolumn{4}{|l|}{ Husband's current work } \\
\hline Works $=1$ & $\begin{array}{l}0.018 \\
(0.35)\end{array}$ & $\begin{array}{l}0.046 \\
(0.67)\end{array}$ & $\begin{array}{l}-0.036 \\
(-0.49)\end{array}$ \\
\hline Temporary Contract & $\begin{array}{l}0.003 \\
(0.07)\end{array}$ & $\begin{array}{l}0.003 \\
(0.04)\end{array}$ & $\begin{array}{l}-0.017 \\
(-0.33)\end{array}$ \\
\hline Public Sector Job & $\begin{array}{l}-0.004 \\
(-0.10)\end{array}$ & $\begin{array}{l}-0.023 \\
(-0.38)\end{array}$ & $\begin{array}{l}0.036 \\
(0.60)\end{array}$ \\
\hline \multicolumn{4}{|l|}{ Contraception } \\
\hline No Family Planning & $\begin{array}{c}0.360 \\
(7.66)^{* *}\end{array}$ & $\begin{array}{c}0.378 \\
(6.38) * *\end{array}$ & $\begin{array}{c}0.336 \\
(4.04) * *\end{array}$ \\
\hline \multicolumn{4}{|l|}{ Husband's Religion } \\
\hline Different than wife's & $\begin{array}{c}0.146 \\
(3.55)^{* *}\end{array}$ & $\begin{array}{c}0.181 \\
(3.16)^{* *}\end{array}$ & $\begin{array}{l}0.085 \\
(1.46) \#\end{array}$ \\
\hline Constant & $\begin{array}{c}-0.472 \\
(-2.95)^{* *}\end{array}$ & $\begin{array}{c}-1.075 \\
(-4.01)^{* *}\end{array}$ & $\begin{array}{l}-0.191 \\
(-0.81)\end{array}$ \\
\hline N. Obs & 4346 & 2431 & 1915 \\
\hline Adj-R Squared & 0.11 & 0.044 & 0.16 \\
\hline
\end{tabular}

Note: OLS estimates include controls for wife's foreign birth, age at marriage, years of marriage, wife's religious affiliation, children out-of-wedlock, size of city and region of residence as well as the couple's education. Significance levels: ** less than 5\%, * less than $10 \%$, \# less than $15 \%$. 
Table 6. Simulated Gap between Current ideal and achieved Fertility (1999 SFS)

\begin{tabular}{lccccc}
\hline $\begin{array}{l}\text { Provincial } \\
\text { unemp. rate } \\
\text { when wife turned }\end{array}$ & \multicolumn{2}{c}{ All } & & Born 1962+ \\
24 & & & & \\
& Inactive & Private work & Public Work & $\begin{array}{c}\text { Private/Temp } \\
\text { Cont. }\end{array}$ & Inactive \\
& & & & 0.154 & 0.131 \\
$6 \%$ & -0.078 & 0.059 & -0.080 & 0.164 & 0.147 \\
$8 \%$ & -0.068 & 0.069 & -0.070 & 0.173 & 0.162 \\
$10 \%$ & -0.059 & 0.078 & -0.061 & 0.182 & 0.177 \\
$12 \%$ & -0.050 & 0.087 & -0.052 & $\mathbf{0 . 1 9 2}$ & 0.193 \\
$14 \%$ & $\mathbf{- 0 . 0 4 0}$ & $\mathbf{0 . 0 9 7}$ & $\mathbf{- 0 . 0 4 2}$ & $\mathbf{0 . 2 0 1}$ & 0.208 \\
$16 \%$ & $\mathbf{- 0 . 0 3 1}$ & $\mathbf{0 . 1 0 6}$ & $\mathbf{- 0 . 0 3 3}$ & 0.210 & 0.223 \\
$18 \%$ & -0.022 & 0.115 & -0.024 & 0.220 & $\mathbf{0 . 2 3 9}$ \\
$20 \%$ & -0.012 & 0.125 & -0.014 & 0.229 & $\mathbf{0 . 2 5 4}$ \\
$22 \%$ & -0.003 & 0.134 & -0.005 & 0.238 & 0.270 \\
$24 \%$ & 0.006 & 0.143 & 0.004 & & \\
\hline
\end{tabular}

Note: Simulations from estimates in columns (1) and (3) of Table 5. All other variables are set at the mean. 